THURSDAY, AUGUST 27, 1874

\section{FIFTH REPORT OF THE SCIENCE COMMISSION}

IHE Fifth Report of the Royal Commission on Science, just issued, is a comparatively short one; but to many it will possess an unusual amount of interest, as showing how far private effort may be relied upon to supply the vast deficiency which at present exists in the means for affording a higher education accessible to all classes.

The Report is concerned with five institutions, each the result of private effort, and each having done much in its own way to raise the standard of the higher education, to place it within the reach of a wider circle, and to bring the physical and natural sciences to the front as indispensable branches of knowledge and an invaluable means of culture, without which all education must be radically incomplete. These institutions are-the two metropolitan Colleges (viz., University and King's Colleges), the Owens College, the Newcastle College of Physical Science, and the Catholic University of Ireland.

The Report gives an account of the origin and growth of cach of these Colleges, founded on abundant data supplied by the authorities of the various institutions. Ample details are given as to the amount and sources of income of each of the five Colleges, the number and kinds of professorships, the income of each Chair, the number of students in each class during the last two ycars--in short, all information needed to form an opinion as to the kind and comprehensiveness of education which the Colleges aim to give, the means at their command to carry out their ideal aims, and the extent to which they have been successful.

The expenditure of University College, London, on capital account, for all purposes, up to the year $\mathbf{I} 870$, amounted to $202,287 l$., the whole having been defrayed out of the original share capital of the College, and out of the sunis that have been either given or bequeathed to it for general purposes from time to time. In addition to the capital sum thus expended there are endowments arising out of various bequests which produced, in 1870 , an annual income of 2,978l. Of this income, $2,276 l$. is appropriated to special purposes; no assistance has ever been received from any Government grant.

The School established in connection with the College is of unquestionable advantage to it, as a large and increasing proportion of well-prepared pupils pass from the former to the latter; and during the last few years the College has been slightly a gainer, in a pecuniary point of view, by the maintenance of the School. The scientific Chairs of the College are eleven in number. Of these eleven professorships, one only is endowed, $\mathrm{Mr}$. T. J. Phillips Jodrell having lately presented to the College the sum of 7,500l. for a permanent endowment of the Chair of Physiology. With the exception of this recent benefaction, the College can hardly be said to possess any endowment whatever the revenue of which is properly applicable to the support of its Scientific Faculty. The Professor of Geology, however, receives 3il. per annum from the Goldsmid Fund.
The courses of study, as indicated in the programmes of the professorial lectures, appear to be carefully arrànged with a view to the requirements both of elementary and of advanced students. Great importance is attached to the laboratory instruction in Physics, Chemistry, and Physiology. The College has but few scholarships or exhibitions, and of these, none are appropriated exclusively to scientific subjects.

The Report of the Council states that during the session 1873-74 the number of pupils was 1,542; of these, 893 were students in the College, and 649 pupils in the School. Of the students, 322 belonged to the Faculty of Medicine. In the Faculties of Arts and Laws and of Science there were 57r. The fees received, exclusive of those for clinical instruction, amounted to 24,2667 . 1os. $6 \%$. The total payments out of these fees to the professors, teachers, and masters, amounted to $16,904 l .8 s .6 d$., leaving 7,36zl. 2s. for the College share of fees.

The evidence which has been laid before the Commission clearly shows that the usefulness of the College is greatly restricted by the insufficiency of funds. The difficulty is felt in two respects : first, in providing adequate payment for the professors and their assistants ; and secondly, in providing laboratory accommodation upon a sufficient scale, together with the proper appliances for instruction and research. The Report gives a schedule of payments to the various scientific professors, followed by a schedule of the lectures given by each; and looked at merely from this point of view alone, the disproportion between the payment and the work done is very striking.

In the opinion of the secretary of the College, "the large deductions from the fees which the College is obliged to make in order to provide for the current expenses of the institution, have a twofold injurious effect. They materially diminish the remuneration of the professors, and so far tend to deprive the College of the services of able men, and by rendering it necessary to charge fees higher than might otherwise be requisite, they must have the indirect effect of keeping down the number of our students. The result is that our professors as a rule are very inadequately paid." The natural consequence of the inadequacy of the professorial stipends is, that in many cases the College has found it impossible to retain the services of some of its most distinguished professors. Some striking instances of very recent occurrence, which show the disadvantage at which the College is placed in this respect, are mentioned in the evidence.

The resources of the College have, moreover, been quite inadequate to provide suitable and sufficient laboratories, apparatus, and assistance for the practical departments of experimental science. The Council have done what they could with the means at their disposal, but these are so inadequate as seriously to cripple the efficiency of the scientific instruction given by the College. Proposals for the extension of the College buildings appear at various times to have come under the consideration of the Council, but no definite action has been taken with regard to them. One of the most important uses to which the additions would be put, were they made, would be laboratories for practical study and original research in connection with the various Science Chairs.

The history and constitution of King's College is in some respects similar to that of University College; by 
its original charter, however, dated 1828 , it is intimately associated with the Church of England. It started at first and has all along had to struggle with even greater difficulties than University College. For new buildings and other purposes it has had to incur debt from time to time, more especially to meet the increased demands of physical science, for which more accommodation is urgently needed.

The expenditure of the capital funds of the College from its foundation up to the present time amounts to I $80,42 \mathrm{I} l .5 \mathrm{~s} . \mathrm{g} d$.

The schedule of payments shows that, as in the case of University College, the teaching staff is very inadequately paid.

The evening classes at King's College have been eminently successful, and provide a fairly complete course of scientific instruction for persons who are unable to attend the day classes. They were attended in 1873 by as many as 550 students, the majority of whom attended more than one class; about 300 out of the 550 attending Science Classes. The financial relations of the School, which is in a flourishing condition, to the College are substantially the same as at University College.

The same complaint is made in the case of King's as in the case of University College; the chief impediment to its further success is "that it is so extremely poor." The various scientific departments of the College do not pay, and were it not for the theological and literary departments, the College, we fear, would have to shut its doors. The professors ought to get three-fourths of the fees, but often a percentage for college expenses has to be deducted from the small sums thus yielded.

We quote in full the recommendations of the Commission with reference to the two Metropolitan Colleges, recommendations which, if carried out, would undoubtedly increase the efficiency of these Colleges, and from which the country would reap a rich return.

"After carefully reviewing the evidence laid before us with regard to University and King's Colleges, and especially taking into account the great public services which have been rendered by these two institutions to scientific education in the metropolis, we are of opinion that, subject to the reservations which we shall make hereafter, they have established a claim to the aid of Government which ought to be admitted. We think that such Government aid should be afforded, both in the form of a capital sum to enable the Colleges to extend their buildings where requisite, and to provide the additional appliances for teaching which the advance of scientific education has now rendered absolutely necessary; and also in the form of an annual grant in aid of the ordinary working expenses of the Colleges.

"With regard to the grant of a capital sum, we are of opinion that it should be appropriated to definite objects such as those above referred to; and we further think that the amount of such grants should be dependent upon the amounts raised by subscription.

"With regard to the annual grants in aid of the income of the Colleges, we think that they aiso should be appropriated to definite purposes, such, for instance, as the augmentation of the stipends of certain professorships, the payment of demonstrators and assistants, or payments in aid of the laboratory and establishment expenses. An account of the yearly expenditure of each institution receiving such assistance should be reported to Government. As the suspension or withdrawal of the annual grant would always remain in the power of Parliament, we do not think that it would be necessary or desirable to give the Crown a voice in the appointment of the professors, or any control over the management of the Colleges, other than such visitatorial jurisdiction as would be implied by an annual presentation of the accounts.

"As we do not consider that a day school in the metropolis ought to receive pecuniary assistance from an institution which is itself in receipt of such assistance from Government, our recommendation of Government aid to University College is subject to the reservation that its financial arrangements shall be such as, while enabling the College to do full justice to the School, may prevent the School from becoming a charge upon the funds of the College on an average of years. Our recommendation is also subject to the reservation that the finances of the Hospital, and of the purely medical departments, shall be kept distinct from those of the College generally. Our inquiry has not extended to Medical Schools, and it is not within our province to make any recommendation with respect to Government aid to such schools, whether associated with scientific colleges or not. In the case of University College, where such an association exists, we think it expedient that the annual outlay on the purely medical department should be kept distinct, in order to enable the Government to consider separately the question of aid to the scientific department. At the same time, we do not think that there is any reason why the Boys School and the Hospital should not continue, as at present, under the manazement and control of the Council of the College.

"The same reservations apply to our recommendations with regard to King's College. Indeed, so far as King's College Hospital and the Medical School connected with it are concerned, the need of such a reservation is more obvious, because it is admitted that these institutions are a heavy burden upon the resources of the College.

"With regard to King's College, we would further suggest that the College should apply for a new Charter, or for an Act of Parliament, with the view of cancelling the proprietary rights of its shareholders, and of abolishing all religious restrictions (so far as any such exist) on the selection of professors of science, and on the privileges extended to students of science. We consider that any grant of public money which may be made to King's College should be conditional on such a reconstitution of the College as should effect these objects. And we suggest that acivantage might be taken of the opportunity thus afforded to introduce into the government of the College such other modifications as the experience of the persons concerned in its management may have shown to be desirable."

(To be continued.)

J. S. K.

THE INTERNATIONAL PREHISTORIC CONGRESS OF ANTHROPOLOGY AND ARCHEEOLOGY-STOCKHOLM MEETING

THIS Congress held its inaugural meeting on Aug.7, and by acclamation elected Count Hamilton its, president, and the gentlemen already mentioned in NATURE (vol. x.p. 307) its acting office-bearers.

There was no further business that day; but the 300 foreign members present (the whole Congress amounts to over $I, 400$ ) were hospitably entertained in the evening by the town of Stockholm at Hasselbacken, which is to Stockholm what Richmond is to London. There were music, supper, and freworks; and during the evening, in reply to a well-worded toast of welcome from the Mayor, several good speeches were delivered by members of the council representing the different nations present.

On Saturday the real work of the Congress began, and 